\title{
Deteksi Residu Oksitetrasiklin pada Ikan Lele yang Dipasarkan di Kota Yogyakarta
}

\author{
(DETECTION OF OXYTETRACYCLINE RESIDUE \\ IN CATFISH MARKETED AT YOGYAKARTA CITY) \\ Nisa Hakimah ${ }^{* 1}$, Wari Pawestri ${ }^{2}$, \\ Dewi Nurmalita Suseno ${ }^{1}$, Sri Widowati Anjarsari ${ }^{3}$ \\ ${ }^{1}$ Progran Studi Teknik Penanganan Patologi Perikanan, \\ Politeknik Kelautan dan Perikanan Sidoarjo, \\ Jl. Raya Buncitan, Gedangan, Dusun Kp. Baru, \\ Buncitan, Sidoarjo, Jawa Timur 61254 \\ ${ }^{2}$ Program Studi Peternakan, Fakultas Pertanian, \\ Universitas Sebelas Maret, Jl. Ir. Sutami No.36A, \\ Pucangsawit, Jebres, Surakarta, Jawa Tengah 57126 \\ ${ }^{3}$ Animal Central Veterinary Clinic, \\ 152, Jalan Tabuan, 93100 Kuching, Sarawak, Malaysia \\ *e-mail: nisahakimah9293@gmail.com
}

\begin{abstract}
ABSTRAK
Tingkat konsumsi ikan di Indonesia terus mengalami peningkatan seiring dengan kesadaran masyarakat terhadap pemenuhan gizi dan meningkatnya pengetahuan tentang manfaat makan ikan bagi tubuh. Kebutuhan ini harus diimbangi dengan peningkatan kuantitas dan kualitas produk ikan. Salah satu kontaminan yang dapat menimbulkan permasalahan adalah cemaran antibiotik. Oksitetrasiklin merupakan antibiotik yang banyak digunakan pada dunia perikanan. Penelitian bertujuan untuk melakukan validasi metode kromatografi cair kinerja tinggi (KCKT) untuk analisis residu oksitetrasiklin dalam daging ikan lele dan melakukan deteksi kejadian residu oksitetrasiklin pada daging ikan lele yang dipasarkan di wilayah Kota Yogyakarta. Penelitian dilakukan dengan dua tahap yaitu tahap validasi dan tahap penelitian lapangan. Validasi metode preparasi sampel daging ikan lele menggunakan alat KCKT dan meliputi parameter spesifisitas, presisi, akurasi,dan linearitas. Hasil penelitian menunjukkan bahwa alat KCKT yang digunakan dalam penelitian dapat digunakan untuk melakukan deteksi residu oksitetrasiklin dalam daging ikan lele dengan baik. Penelitian lapangan menggunakan 59 sampel ikan lele yang diambil dari penjual yang berbeda di 16 pasar tradisional wilayah Kota Yogyakarta. Hasil penelitian menunjukkan adanya residu oksitetrasiklin, ditunjukkan dengan hasil positif (melampaui batas maksimum residu) pada $25 \%$ dari keseluruhan sampel.
\end{abstract}

Kata-kata kunci: ikan lele; oksitetrasiklin; residu; KCKT

\begin{abstract}
The fish consumption in Indonesia is increasingas well as the public awareness of daily nutrients needed and knowledge about the benefits of eating fish for health. Thus an enhancement in the quantity and quality of fish products should be made to make it balance. One of the factors affected the fish product's quality is the use of antibiotics, as it is widely used in fisheries and potentially dangerous for its contamination. Oxytetracycline is a common antibiotic used in fisheries. The study was carried out to validate high performance liquid chromatography (HPLC) method to analyze and to detect the occurrence of oxytetracycline residues in catfish carcass marketed in Yogyakarta City. The research was conducted in two stages, the validation stage and the field research stage. Validation of catfish carcass sample was done using HPLC (Shimadzu version 6.1.) with parameters of specificity, precision, accuracy, and linearity. The results of the study showed that the HPLC method used in the study was able to detect oxytetracycline residues in catfish carcass. The field research was done using 59 samples taken from different sellers in 16 traditional markets in Yogyakarta City. It was showed that 25\% (above maximum residue limits) of the samples were contaminated as the residues of oxytetracycline were detected.
\end{abstract}

Keywords: catfish; oxytetracycline; residue; HPLC 


\section{PENDAHULUAN}

Tingkat konsumsi ikan nasional di Indonesia diperkirakan mencapai 55,95 kg/kapita/ tahun pada tahun 2019 dan diperkirakan akan terus mengalami peningkatan seiring dengan kesadaran masyarakat terhadap manfaat mengonsumsi ikan untuk tubuh manusia (Kementerian Kelautan dan Perikanan, 2020). Ikan lele (Clarias sp.) merupakan salah satu jenis ikan yang banyak dikonsumsi oleh masyarakat Indonesia (Kementerian Kelautan dan Perikanan Republik Indonesia, 2015). Peningkatan konsumsi ikan harus diimbangi dengan peningkatan jumlah produksi, penguatan jaminan keamanan, mutu, dan gizi pangan. Produk pangan asal hewan yang tidak aman untuk dikonsumsi dapat menimbulkan permasalahan kesehatan bagi konsumen. Salah satu kontaminan yang berbahaya adalah kandungan bahan kimia dalam produk, termasuk antibiotik.

Oksitetrasiklin merupakan antibiotik yang banyak digunakan pada perikanan karena mudah diperoleh dengan harga terjangkau (Orlando dan Samionato, 2013). Oksitetrasiklin digunakan tidak hanya untuk pengobatan tetapi digunakan juga sebagai growth promotor pada ikan untuk meningkatkan efisiensi pakan dan laju pertumbuhan (Nguyen et al., 2014). Oksitetrasiklin merupakan antibiotik spektrum luas dan bersifat bakteriostatik atau bakterisidal. Penggunaan antibiotik dalam jangka waktu panjang, tidak terkendali, dan tanpa pengawasan dapat menyebabkan akumulasi residu pada organ atau jaringan tubuh hewan (Canada et al., 2009).

Residu antibiotik merupakan salah satu cemaran kimia dalam pangan yang mengancam kesehatan manusia meliputi efek toksik, keracunan, gangguan pencernaan, gagalnya pengobatan akibat resistansi, dan gangguan mikroflora dalam saluran pencernaan (Pawestri, 2019). Akumulasi residu terjadi karena senyawa yang masuk ke dalam tubuh hewan tidak dapat diekskresikan seluruhnya dan tertinggal di dalam jaringan. Batas maksimum residu (BMR) oksitetrasiklin yang ditetapkan oleh Badan Standardisasi Nasional (2000) untuk daging adalah $0,1 \mathrm{mg} / \mathrm{kg}$. Residu antibiotik pada produk pangan yang melebihi BMR dapat menurunkan kualitas keamanan produk dan mengancam kesehatan masyarakat (Utami et al., 2016). Permasalahan yang dapat muncul dapat berupa resistensi bakteri, alergi terhadap pangan, dan keracunan (Dewi et al., 2014).
Salah satu teknologi analisis yang dapat digunakan untuk mendeteksi residu antibiotik adalah alat kromatografi cair kinerja tinggi (KCKT). Kromatografi cair kinerja tinggi menggunakan teknologi kolom dengan sistem pompa tekanan tinggi dan detektor yang sensitif. Alat ini mempunyai kemampuan untuk memisahkan senyawa kimia dengan efektif dan tingkat efisiensi yang tinggi (Anastasia, 2011). Metode KCKT memiliki keunggulan yaitu kecepatan analisis tinggi, daya pisah baik, peka, ideal untuk molekul besar dan ion, mudah untuk mendapatkan recovery yang baik, kolom dapat digunakan berulang kali, serta dalam teknik penggunaannya tidak memerlukan keahlian khusus (Johnson dan Stevenson, 1991).

Penelitian ini dilakukan dengan tujuan untuk melakukan validasi metode kromatografi cair kinerja tinggi (KCKT) untuk analisis residu oksitetrasiklin dalam daging ikan lele, dan melakukan deteksi kejadian residu oksitetrasiklin pada daging ikan lele yang dipasarkan di wilayah Kota Yogyakarta. Metode analisis dengan alat KCKT memiliki beberapa kelebihan meliputi waktu analisis cepat, jumlah sampel yang diperlukan sedikit, kepekaan yang tinggi, dapat digunakan pada sampel organik atau anorganik, memiliki daya pisah molekul yang baik, dapat menggunakan berbagai macam detektor, dan kolom yang telah digunakan dapat digunakan kembali (Sabrina et al., 2012). Modifikasi metode KCKT dilakukan berdasarkan penelitian-penelitian yang telah dilakukan sebelumnya, di antaranya adalah penelitian Senyuva et al. (2000), Wijayanti et al. (2007), Badan Standardisasi Nasional (2009), Anastasia (2011), Hussien (2014), Mahmoudi et al. (2014), dan Hakimah et al. (2019). Modifikasi metode KCKT dilakukan dengan tujuan untuk mendapatkan hasil yang optimal dalam melakukan analisis residu oksitetrasiklin dalam jaringan otot/daging ikan lele, terutama dengan alat yang tersedia di laboratorium. Penelitian mengenai deteksi residu antibiotik oksitetrasiklin pada ikan di Nigeria pernah dilakukan oleh Olatoye dan Afisu (2013). Penelitian tersebut sebagai sumber referensi peneliti dalam mengembangkan penelitian ini.

Penelitian diharapkan dapat memberikan informasi kepada masyarakat baik produsen maupun konsumen, sehingga meningkatkan perhatian dan kesadarannya akan keamanan pangan. Metode yang dikembangkan dalam penelitian ini juga dapat menjadi alternatif prosedur standar analisis oksitetrasiklin serta 
dapat dijadikan dasar pengembangan teknologi analisis yang lebih efektif dan efisien.

\section{METODE PENELITIAN}

Alat utama yang digunakan dalam penelitian ini berupa seperangkat alat kromatografi cair kinerja tinggi (KCKT) dengan merek Shimadzu versi 6.1. Alat KCKT menggunakan sistem kontrol SCL-10 A VP, detektor UV-Vis SPD 10 AV VP, pompa LC-10 AD VP, degasser DGU-14A, oven CTO-10 AC VP, dan kolom Clipeus $\mathrm{C}_{18} 4,6 \times 150 \mathrm{~mm}$. Alat lain yang digunakan adalah vortex mixer, sentrifus (Centrifuge PLC), ultrasonic bath (Elma), erlenmeyer, eppendorf tube, syringe 25F-LC, dan seperangkat komputer.

Prosedur pengoperasian alat KCKT dilaksanakan berdasarkan pada modifikasi penelitian yang telah dilakukan oleh Wijayanti et al., (2007), Hakimah (2019), dan mengacu pada standar Association of Official Analytical Chemistry (2002). Analisis dilakukan dengan laju alir fase gerak sebesar $1 \mathrm{~mL} /$ menit, dengan suhu oven $30^{\circ} \mathrm{C}$, detektor UV-Vis dengan panjang gelombang $355 \mathrm{~nm}$, dan jumlah injeksi $20 \mu \mathrm{L}$.

Dalam analisis residu, digunakan fase gerak yang merupakan campuran dari methyl alcohol 99,9\% (J.T. Baker), acetonitrile 99,9\% (J.T. Baker), dan oxalic acid dehydrate $0,126 \%$ (J.T. Baker) dalam aqua bidestilata (PT. Ikapharmindo Putramas) dengan perbandingan 5 : 15 : 80. Buffer McIlvaine digunakan sebagai pelarut larutan standar oksitetrasiklin dan digunakan dalam tahap preparasi sampel jaringan ikan lele, dibuat berdasarkan Badan Standardisasi Nasional (2009). Buffer McIlvaine ini terdiri dari campuran disodium hydrogen phosphate (Merck), citric acid monohydrate (Merck), ethylene dinitrilotetraacetic acid (Merck), dan aqua bidestilata. Penelitian ini terdiri dari dua tahap yaitu uji validasi pengukuran oksitetrasiklin dengan KCKT dan pemeriksaan residu oksitetrasiklin di dalam daging ikan lele.

\section{Uji Validasi Pengukuran Oksitetrasiklin dengan KCKT}

Pembuatan Larutan Standard. Oksitetrasiklin murni yang digunakan untuk validasi adalah oxytetracycline hydrochloride (Sigma). Sebanyak $10 \mathrm{mg}$ oxytetracycline hydrochloride dalam $10 \mathrm{~mL}$ buffer McIlvaine sebagai larutan standar baku. Pengenceran selanjutnya dilakukan dengan menggunakan pelarut buffer McIlvaine sehingga diperoleh larutan oksitetrasiklin dengan konsentrasi $0,2 \mu \mathrm{g} / \mathrm{mL}$; $0,175 \mu \mathrm{g} / \mathrm{mL} ; 0,15 \mu \mathrm{g} / \mathrm{mL} ; 0,1 \mu \mathrm{g} / \mathrm{mL} ; 0,075 \mu \mathrm{g} /$ $\mathrm{mL}$; dan $0,05 \mu \mathrm{g} / \mathrm{mL}$ dan dilakukan spiking pada jaringan daging lele sesuai prosedur yang dijelaskan selanjutnya. Validasi yang dilakukan pada penelitian ini meliputi parameter spesifisitas, presisi, akurasi, dan linearitas.

Ekstraksi Jaringan. Ekstraksi sampel jaringan dilakukan dengan menghaluskan daging ikan lele bagian kaudal sebelah kanan. Daging ikan yang telah dihaluskan ditimbang seberat $1 \mathrm{~g}$ dan dimasukkan ke dalam tabung konikel pertama. Sampel tersebut dilakukan spiking larutan oksitetrasiklin pada masingmasing sampel sehingga mengandung $2 \mu \mathrm{g} / \mathrm{g}$; $1,75 \mu \mathrm{g} / \mathrm{g} ; 1,5 \mu \mathrm{g} / \mathrm{g} ; 1 \mu \mathrm{g} / \mathrm{g} ; 0,75 \mu \mathrm{g} / \mathrm{g}$; dan $0,5 \mu \mathrm{g} /$ g. Buffer McIlvaine sebanyak $5 \mathrm{~mL}$ ditambahkan ke dalam konikel pertama kemudian dihomogenkan dengan menggunakan vortex mixer selama 30 detik. Buffer McIlvaine sebanyak $4 \mathrm{~mL}$ ditambahkan ke dalam konikel pertama. Konikel dihomogenkan menggunakan vortex mixer selama 30 detik dan dimasukkan ke dalam sentrifus selama 10 menit dengan kecepatan 2.500 g. Supernatan diambil, disaring, dan ditampung pada tabung konikel kedua. Tabung konikel pertama ditambahkan buffer Mcllvaine sebanyak $4 \mathrm{~mL}$, dicampur dengan vortex mixer selama 30 detik, dan dimasukkan ke dalam sentrifus selama 10 menit dengan kecepatan 2.500 g. Supernatan selanjutnya ditambahkan pada tabung kedua.

Sisa homogenat tabung pertama dibilas kembali dengan menggunakan $2 \mathrm{~mL}$ buffer McIlvaine, dicampur dengan menggunakan vortex mixer selama 30 menit, dan dimasukkan ke dalam sentrifus selama 10 menit dengan kecepatan 2.500 g. Supernatan ditambahkan kembali pada tabung kedua yang selanjutnya supernatan kolektif pada tabung kedua dimasukkan ke dalam sentrifus selama 20 menit dengan kecepatan $2.500 \mathrm{~g}$ dan disaring ke tabung ketiga serta diberi label.

\section{Pemeriksaan Residu Oksitetrasilin di Dalam Daging Ikan Lele}

Sampel yang digunakan untuk penelitian lapangan adalah 59 ekor ikan lele yang diambil dari 59 penjual ikan di 16 pasar tradisional di Kota Yogyakarta. Beberapa informasi tambahan didapatkan dari kuesioner yang diisi oleh penjual ikan, yang ditunjang dengan wawancara dan pengamatan langsung di pasar. 
Sampel ikan yang diambil dari pasar tradisional di Kota Yogyakarta dimasukkan dalam kontainer dan dikirim ke Laboratorium Farmakologi Fakultas Kedokteran Hewan Universitas Gadjah Mada untuk dianalisis menggunakan alat kromatografi cair kinerja tinggi yang telah tervalidasi. Hasil penelitian lapangan dianalisis secara deskriptif.

\section{HASIL DAN BAHASAN}

\section{Uji Validasi Pengukuran Oksitetrasiklin dengan KCKT}

Parameter yang digunakan untuk melaksanakan validasi ini adalah spesifisitas, presisi, akurasi, dan linearitas. Riyanto (2014) menyatakan bahwa kemampuan suatu metode untuk mengukur zat tertentu secara spesifik dengan adanya komponen lain dalam sampel dapat dilakukan validasi dengan membandingkan hasil analisis sampel yang mengandung oksitetrasiklin dengan sampel tanpa penambahan bahan lain (blanko). Kromatogram hasil analisis yang ditunjukkan pada Gambar 1 dan Gambar 2 menunjukkan bahwa area puncak oksite- trasiklin muncul pada kisaran menit ke- 4,8 sampai menit ke-5,2. Hasil kromatogram menunjukkan bahwa spesifisitas metode analisis yang digunakan baik. Karena metode ini mampu memberikan hasil luas area yang spesifik pada waktu tertentu sesuai dengan jumlah oksitetrasiklin yang ditambahkan.

Presisi dinyatakan sebagai relative standard deviation (\% RSD), dan ditetapkan sebagai hasil yang baik apabila nilai RSD $\leq 2 \%$ (Sugihartini et al., 2014). Pada Tabel 1 disajikan bahwa metode analisis yang digunakan dalam penelitian ini adalah baik karena nilai RSD $\leq$ $2 \%$ yang berarti mampu mendeteksi oksitetrasiklin dengan nilai luas area yang tetap pada konsentrasi tertentu (Sugihartini et al., 2014).

Akurasi merupakan ukuran yang menyatakan derajat kedekatan antara hasil analisis dengan kadar analit sebenarnya (Hariyanto et al., 2008). Akurasi dapat ditunjukkan dengan persen perolehan kembali. Nilai kisaran yang dapat diterima adalah 80 $120 \%$ (FDA, 2001). Berdasarkan hasil analisis yang dapat diamati pada Tabel 1 menunjukkan bahwa nilai perolehan kembali antara $96-110 \%$

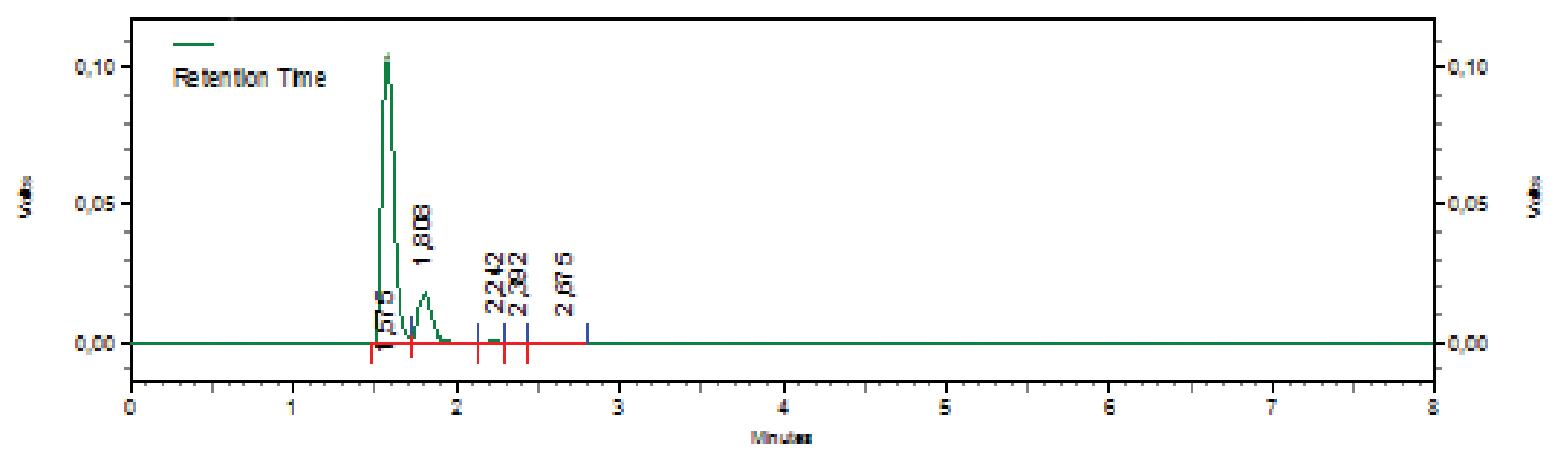

Gambar 1. Kromatogram kromatografi cair kinerja tinggi (KCKT) sampel blangko

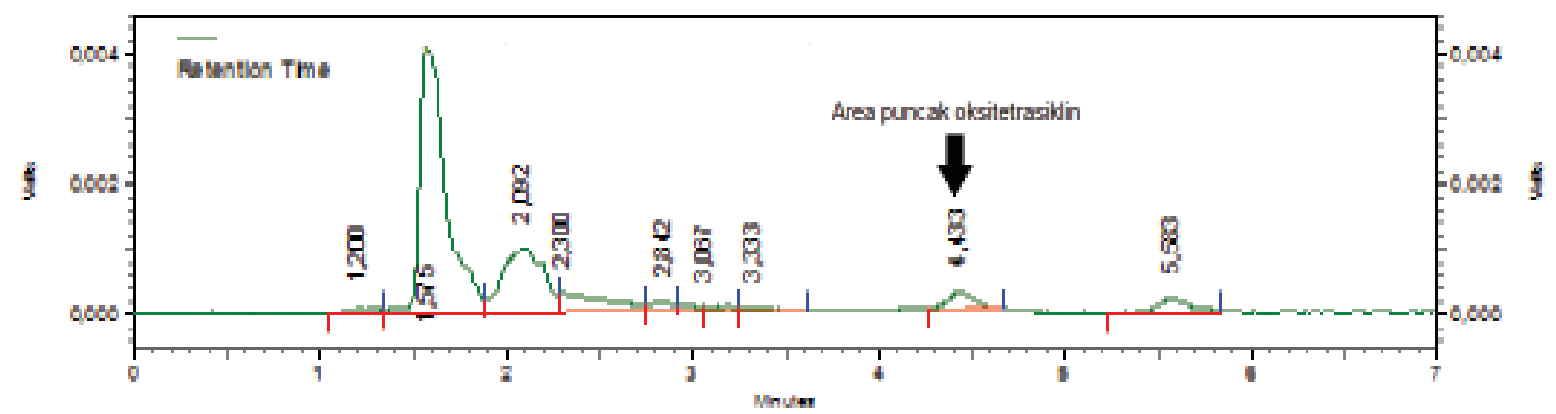

Gambar 2. Kromatogram kromatografi cair kinerja tinggi (KCKT) sampel yang ditambahkan oksitetrasiklin $0,5 \mu \mathrm{g} / \mathrm{g}$ 
Tabel 1. Hasil uji presisi dan akurasi analisis oksitetrasiklin dalam daging ikan lele dengan kromatografi cair kinerja tinggi (KCKT)

\begin{tabular}{cccc}
\hline $\begin{array}{c}\text { Konsentrasi } \\
\text { oksitetrasiklin }(\mu \mathrm{g} / \mathrm{g})\end{array}$ & $\begin{array}{c}\text { Rata-rata luas area } \\
\pm \text { standar deviasi }\end{array}$ & RSD (\%) & $\begin{array}{c}\text { Nilai perolehan } \\
\text { kembali (\%) }\end{array}$ \\
\hline 0,50 & $1293,33 \pm 11,39$ & 0,09 & 110 \\
0,75 & $1616,67 \pm 121,71$ & 0,08 & 96 \\
1,00 & $2072,33 \pm 59,18$ & 0,03 & 97 \\
1,25 & $2649,67 \pm 36,19$ & 0,01 & 98 \\
1,50 & $3018,67 \pm 105,99$ & 0,04 & 98 \\
1,75 & $3474,33 \pm 23,5$ & 0,01 & 102 \\
2,00 & $4092,67 \pm 47,06$ & 0,01 & 08 \\
\hline
\end{tabular}

\section{Linearitas Sampel Daging Ikan Lele yang Ditambahkan} Oksitetrasiklin

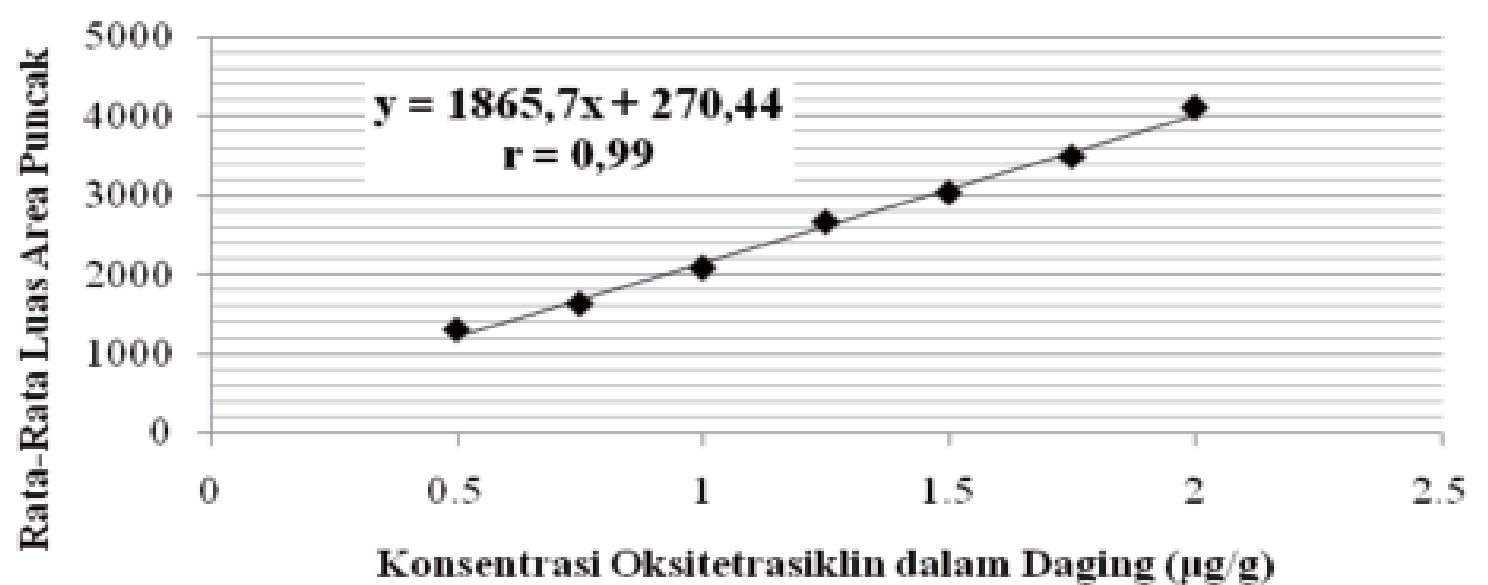

Gambar 3. Hasil uji linearitas pemeriksaan residu oksitetrasiklin dengan kromatografi cair kinerja tinggi (KCKT)

yang berarti metode analisis yang digunakan dalam penelitian ini memiliki akurasi yang baik dengan nilai perolehan $100 \%$. Hal ini sesuai dengan Perdian et al., (2015), bahwa akurasi yang dikatakan baik dapat ditunjukkan dengan nilai perolehan kembali mendekati $100 \%$.

Menurut Lindholm (2004), linearitas merupakan kemampuan suatu metode dalam menghasilkan hasil pengujian yang proporsional terhadap konsentrasi analit dalam sampel dengan mengukur larutan standar pada konsentrasi bertingkat (minimal lima titik). Linearitas yang baik akan menunjukkan nilai $r \geq 0,99$ (AOAC, 2002). Hal ini sesuai dengan hasil pengujian linearitas yang ditunjukkan pada Gambar 3. diperoleh suatu persamaan lineary $=1865,7 x+270,44$ dengan nilai koefisien korelasi (r) sebesar 0,99. Berdasarkan hasil linearitas pemeriksaan residu oksitetrasiklin pada sampel daging ikan lele menunjukkan bahwa metode analisis yang digunakan dalam penelitian ini adalah baik.

\section{Residu Oksitetrasiklin pada Ikan Lele yang Dipasarkan di Yogyakarta}

Penelitian ini bertujuan untuk melakukan deteksi kejadian residu oksitetrasiklin pada ikan lele yang dipasarkan di Kota Yogyakarta. Hasil penelitian terkait kejadian residu oksitetrasiklin pada daging ikan lele yang dipasarkan di Kota Yogyakarta disajikan pada Tabel 2.

Hasil analisis residu menggunakan KCKT menunjukkan bahwa secara keseluruhan diketahui 25\% daging ikan lele yang dipasarkan di pasar tradisional Kota Yogyakarta positif mengandung oksitetrasiklin dengan kisaran residu pada sampel positif sebesar $0,14-0,90 \mathrm{mg} /$ $\mathrm{kg}$ (di atas batas maksimum residu). Kadar residu tersebut berada di atas batas maksimum residu (BMR) yang diizinkan. Badan Standar- 
Tabel 2. Kejadian residu oksitetrasiklin pada ikan lele yang dipasarkan di Yogyakarta

\begin{tabular}{|c|c|c|c|c|}
\hline Nama pasar & $\begin{array}{l}\text { Jumlah } \\
\text { sampel }\end{array}$ & $\begin{array}{l}\text { Kisaran residu } \\
\quad(\mathrm{mg} / \mathrm{kg})\end{array}$ & $\mathrm{SD}$ & Asal Ikan \\
\hline Gedongkuning & 3 & 0,79 & $\pm 0,46$ & Klaten, Boyolali \\
\hline Demangan & 12 & $0,15-0,9$ & $\pm 0,28$ & $\begin{array}{l}\text { Boyolali, Wonogiri, Kota } \\
\text { Yogyakarta, Klaten, Semarang }\end{array}$ \\
\hline Prawirotaman & 7 & 0,49 & $\pm 0,19$ & Klaten, Semarang, Ambarawa \\
\hline Kranggan & 7 & $0,14-0,44$ & $\pm 0,13$ & $\begin{array}{l}\text { Sleman, Semarang, Solo, } \\
\text { Wonogiri, Boyolali, } \\
\text { Tulungagung }\end{array}$ \\
\hline $\begin{array}{l}\text { Sentul } \\
\text { Solo }\end{array}$ & 4 & 0,15 & $\pm 0,07$ & Klaten, Kuningan, Wonogiri, \\
\hline Ngasem & 2 & 0,15 & $\pm 0,05$ & Kota Yogyakarta, Klaten \\
\hline Gondomanan & 1 & 0,37 & - & Kota Yogyakarta \\
\hline Talok & 1 & 0,36 & - & Klaten, Sleman \\
\hline Bringharjo & 6 & 0 & - & Semarang, Klaten \\
\hline Lempuyangan & 2 & 0 & - & Bantul, Sragen \\
\hline Legi & 1 & 0 & - & $\begin{array}{l}\text { Kota Yogyakarta, Purwodadi, } \\
\text { Semarang }\end{array}$ \\
\hline Serangan & 2 & 0 & - & Klaten \\
\hline Ngadikusuman & 2 & 0 & - & Semarang, Klaten \\
\hline Giwangan & 3 & 0 & - & Klaten, Wonogiri \\
\hline Karangwaru & 2 & 0 & - & Klaten \\
\hline Kotagede & 4 & 0 & - & Boyolali, Semarang, Boyolali \\
\hline
\end{tabular}

Total sampel

59

disasi Nasional (2000) menetapkan BMR untuk antibiotik oksitetrasiklin pada daging $0,1 \mathrm{mg} /$ kg. Konsumsi pangan asal hewan yang mengandung antibiotik diperbolehkan asalkan berada di bawah BMR yang ditetapkan (Nurhasnawati et al., 2016).

Ikan lele yang diperjualbelikan di Kota Yogyakarta masih belum bebas dari residu antibiotik oksitetrasiklin. Hal ini sesuai dengan, hasil analisis statistika yang menunjukkan bahwa daging ikan lele yang berasal dari Pasar Demangan berpeluang lebih besar mengandung residu antibiotik oksitetrasiklin, dan daging ikan lele yang dipasarkan di Pasar Bringharjo berpeluang untuk tidak mengandung residu oksitetrasiklin dibandingkan dengan ikan lele yang dipasarkan di pasar lain di Kota Yogyakarta. Faktor-faktor risiko yang diduga berhubungan dengan kejadian residu oksitetrasiklin pada ikan diduga berkaitan dengan penggunaan antibiotik sebagai bahan tambahan pakan, adanya kontaminasi antibiotik pada air yang digunakan sebagai pemeliharaan ikan, dan adanya endapan sisa antibiotik yang mencemari tanah di kolam
(Pawestri, 2019).

Oksitetrasiklin dapat masuk ke dalam tubuh melalui penyerapan dari air, secara injeksi, maupun per oral (Noga, 2010). Oksitetrasiklin dapat diabsorbsi mencapai 60$80 \%$ melalui saluran gastrointestinal, absorbsi oksitetrasiklin secara per oral terjadi pada usus halus bagian atas (Kee dan Hayes, 1994) dan diekskresikan dalam urin melalui filtrasi glomerulus sekitar 60\% dan melalui feses sekitar 40\% (Noga, 2010). Oksitetrasiklin merupakan jenis obat yang mudah larut dalam lemak serta terdistribusi dengan baik ke jaringan tubuh sehingga memiliki waktu eliminasi yang cukup lama dalam jaringan (Wijayanti et al., 2010). Hal tersebut mengakibatkan tingginya kadar residu obat dalam jaringan.

Keberadaan residu antibiotik pada produk hewani disebabkan oleh beberapa faktor yaitu penggunaan antibiotik yang melebihi dosis anjuran, waktu henti obat, kurangnya pengawasan dari dokter hewan, pengetahuan yang kurang mengenai dampak pada kesehatan masyarakat akibat mengonsumsi produk asal hewan yang mengandung antibiotik, tidak ada 
penyuluhan dalam penggunaan antibiotik yang baik dan benar di lokasi budidaya (Masrianto et al., 2013). Terdapat dugaan lain yaitu pakan komersial yang diberikan pada waktu pemeliharaan ikan lele mengandung antibiotik (Saniwanti et al., 2015).

Kejadian residu oksitetrasiklin pada daging ikan lele yang dipasarkan di pasar tradisional Kota Yogyakarta diduga tidak berhubungan secara langsung dengan kondisi pasar. Namun, juga berkaitan dengan kondisi ikan sejak saat berada di lokasi budidaya, distributor, dan atau pedagang. Hal ini diduga terkait dengan manajemen pemeliharaan, manajemen pakan, tindakan pengobatan, lingkungan, sumber air, proses pengangkutan, tempat penyimpanan, dan sebagainya. Hal yang berhubungan langsung dengan lokasi pasar, dapat dikaitkan dengan higienitas, sumber air, penyajian ikan, dan penyimpanan ikan. Hal ini juga didukung oleh penelitian yang dilakukan oleh Turk dan Halis (2016) yang menyatakan bahwa antibiotik golongan tetrasiklin merupakan sumber kontaminasi untuk ekosistem karena harganya murah, digunakan dalam pengobatan manusia dan hewan, sebagai aditif pakan dalam produksi, serta tahan terhadap kondisi lingkungan. Oksitetrasiklin dapat tetap utuh selama hampir enam bulan pada sedimen laut.

\section{SIMPULAN}

Berdasarkan penelitian dapat disimpulkan bahwa metode yang diaplikasikan dalam penelitian ini dapat digunakan untuk melakukan deteksi residu oksitetrasiklin dalam daging ikan lele dengan baik. Dari penelitian lapangan diketahui bahwa $25 \%$ daging ikan lele yang dipasarkan di pasar tradisional Kota Yogyakarta positif mengandung oksitetrasiklin dengan kisaran sebesar 0,14-0,90 mg/kg dan melampaui batas maksimum residu yang diperbolehkan.

\section{UCAPAN TERIMA KASIH}

Penelitian ini merupakan bagian dari rangkaian penelitian dan masih terus dikembangkan. Terima kasih kepada Dinas Penanaman Modal dan Perizinan Pemerintah Kota Yogyakarta yang telah memberikan izin dalam pengambilan sampel ikan di pasar tradisional Kota Yogyakarta serta pihak
Fakultas Kedokteran Hewan UGM dan Dr drh Raden Gagak Donny Satria, MP, MPd. yang telah turut membantu penelitian ini melalui pendanaan Penelitian Kompetitif Fakultas.

\section{DAFTAR PUSTAKA}

Anastasia Y. 2011. Teknik Analisis Residu Tetrasiklin Golongan Tetrasiklin dalam Daging Ayam secara Kromatografi Cair Kinerja Tinggi. Buletin Teknik Pertanian 16(2): 68-73.

AOAC (Association of Official Analytical Chemists). 2002. International Methods Committee Guidelines for Validation of Qualitative and Quantitative Food Microbiological Official Methods of Analysis. J AOAC Int 85: 1-5. DOI: 10.1093/jaoac/ 85.5.1187

Dewi A, Widdhiasmoro NP, Nurlatifah I, Riti N, Purnawati D. 2014. Residu Antibiotika pada Pangan Asal Hewan, Dampak, dan Upaya Penanggulangannya. Buletin Veteriner 26: 85.

Badan Standardisasi Nasional. (2000). Batas Maksimum Cemaran Mikroba dan Batas Maksimum Residu dalam Bahan Makanan Asal Hewan (SNI 01-6366-2000). Jakarta, DKI: Penulis. Diakses dari http:// bpmsph.org/tanggal 11 Desember 2019.

Badan Standardisasi Nasional. (2009). Cara Uji Kimia-Bagian 11: Penentuan Residu Tetrasiklin dan Derivatnya dengan Kromatografi Cair Kinerja Tinggi (KCKT) pada Produk Perikanan (SNI 2354. 11: 2009). Jakarta, DKI: Penulis. Diakses dari http://www.bkipm.kkp.go.id tanggal 9 Desember 2019.

Canada FC, de La Pena AM, Espinosa-Mansilla A. 2009. Analysis of Antibiotic in Fish Sample. Analytical and Bioanalytical Chemistry 395: 987-1008. DOI: 10.1009/ s00216-009-2872-z

FDA (Food and Drug Administration). 2001. Guidance for Industry: Bioanalytical Method Validation. Rockville USA. Center for Drug Evaluation and Research. Hlm. 6.

Hakimah N, Satria RGD, Wari P, Soedarmanto I. 2019. Validasi Metode Analisis Tetrasiklin pada Ikan Nila (Oreochromis sp.) Menggunakan Alat Kromatografi Cair 
Kinerja Tinggi (KCKT). Jurnal Sain Veteriner 37(2): 213-218. DOI: 10.22146/ jsv.34466

Hariyanto G, Kardono LBS, Manysur U. 2008. Validasi Metode Penetapan Kadar Dehidrolovastatin dalam Plasma In Vitro dengan KCKT. Majalah Ilmu Kefarmasian 5(3): $75-83$.

Hussien EM. 2014. HPLC Method Validation for Modernization of the Tetracycline Hydrochloride Capsule USP Monograph. Bulletin of Faculty Pharmacy 52(2): 239244. DOI: https://doi.org/10.1016/ j.bfopcu.2014.08.002

Johnson EL, Stevenson R. 1991. Dasar Kromatografi Cair. Bandung. ITB Press.

Kee J, Hayes ER. 1994. Farmakologi Pendekatan Proses Keperawatan. Jakarta. Buku Kedokteran ECG.

Kementerian Kelautan dan Perikanan Republik Indonesia. 2015. Pengendalian Residu Obat Ikan, Bahan Kimia, dan Kontaminan pada Kegiatan Pembudidayaan Ikan Konsumsi (Permenkp Nomor 39 Tahun 2015). Jakart, DKI: Penulis. Diakses dari http:// jdih.kkp.go.id tanggal 11 Desember 2019.

Kementerian Kelautan dan Perikanan. 2020. Siaran Pers. Diakses dari https://kkp.go.id/ artikel/16451-2020-kkp-tanggal 15 Maret 2020.

Lindholm J. 2004. Development and Validation of HPLC Methods for Analitical and Preparative Purpose. Diakses dari http:// www.diva-portal.org tanggal 9 Desember 2019.

Mahmoudi R, Gajarbeygi P, Norian R, Farhoodi K. 2014. Chloramphenicol, Sulfonamide, and Tetracycline Residues in Cultured Rainbow Trout Meat (Oncorhynchus mykiss). Bulgarian Journal Vet Medicine 17(2): 147152.

Masrianto, Fakhrurrazi, Azhari. 2013. Uji Residu Antibiotik pada Daging Sapi yang Dipasarkan di Pasar Tradisional Kota Banda Aceh. Jurnal Medikal Veterinaria 7(1): 13-14.

Nguyen F, Starosta AL, Arenz S, Sohmen D, Donhofer A, Wilson DN. 2014. Tetracycline Antibiotics and Resistance Mechanism. Biol Chem 395(1): 559-575.
Noga E. 2010. Fish Disease Diagnosis and Treatment. Second Ed. New Jersey. Wiley Blackwell.

Nurhasnawati H, Jubaidah S, Elfia N. 2016. Penentuan Kadar Residu Tetrasiklin $\mathrm{HCl}$ pada Ikan Air Tawar yang Beredar di Pasar Segiri Menggunakan Metode Spektrofotometri Ultra Violet. Jurnal ilmiah Manuntung 2(2): 6.

Olatoye IO, Basiru A. 2013. Antibiotic Usage and Oxytetracycline Residu in African Catfish (Clarias gariepinus in Ibadan, Nigeria). World Journal Fish and Marine Science 5(3): 302-309.

Orlando EA, Samionato AVC. 2013. Extraction of Tetracycline Antibiotic Residues from Fish Fillet: Comparison and Optimization of Different Procedure Using Liquid Chromatography with Flouroscent Detection. Journal Chromatography A 1307: 111-118. DOI: 10.1016/j.chroma. 2013.07.084

Pawestri W, RGD Satria, Nisa H, Doddi Y. 2019. Deteksi Kejadian Residu Tetrasiklin pada Daging Ikan Nila di Kota Yogyakarta dengan Kromatografi Cair Kinerja Tinggi (KCKT). Jurnal Sain Veteriner 37(2): 185192. DOI: $10.22146 /$ jsv. 34463

Perdian HA, Herawati D, Arumsari A. 2015. Studi Pendahuluan Analisis Antibiotik Golongan Tetrasiklin Menggunakan Metode Kromatografi Cair Kinerja Tinggi. Prosiding Penelitian SPeSIA, 1-6. Diakses dari http://repository.unisba.ac.id tanggal 3 Desember 2019.

Riyanto. 2014. Validasi dan Verifikasi Metode Uji sesuai dengan ISO/IEC 17025 Laboratorium Penguji dan Kalibrasi. Yogyakarta. CV Budi Tama.

Rohman A. 2009. Kromatografi untuk Analisis Obat. Yogyakarta. Graha Ilmu.

Sabrina A, Wonorahardjo S, Zakia N. 2012. Perbandingan Metode Spektofotometri UVVis dan KCKT (Kromatografi Cair Kinerja Tinggi) pada analisis Kadar Asam Benzoate dan Kafein Teh Kemasan. Jurnal Universitas Negeri Malang 1: 1.

Saniwanti., Nuraini., Dian, A (2015). Studi Residu Antibiotik Daging Broiler yang Beredar di Pasar Tradisional Kota Kendari. Jurnal Ilmu dan Teknologi Peternakan Tropis 1(3): 30-38. 
Senyuva H, Tuncel O, Deniz YS. 2000. High Performance Liquid Chromatographic Determination of Oxytetracycline Residue in Cured Meat Products. Turk J Chem 24(1): 395-400.

Sugihartini, N., Fudholi, A., Pramono, S., Sismindari. (2014). Validasi Metode Analisa Penetapan Kadar Epigalokatekin Galat dengan Kromatografi Cair Kinerja Tinggi. Pharmaciana, 4 (2): 111-115. Diakses dari http://journal. uad.ac.id

Turk E, Halis O. 2016. Investigation of Tetracycline Residues in Fish Caught from Surrounding Fish Farms in Mugla District. Eurasian J Vet Sci 32 (2): 74-79.
Utami BS, Razanah H, Pravitasari PD, Permata FI, Rafrensca AR. 2016. Deteksi Cepat Residu Tetrasiklin Melalui STARTEC (Smart Tetracycline Residual Kit Detection). Jurnal Aplikasi Teknologi Pangan 5(4): 151153.

Wijayanti A, Lukman H, Irkham W. 2007. Profil Farmakokinetik Oksitetrasiklin Hidroklorid dalam Berbagai Jaringan Tikus Sprague dawley. Jurnal Sain Vet 25: 6874 .

Wijayanti A, Lukman H, Irkham W, Irianti T. 2010. Penentuan Efektifitas Oksitetrasiklin Melalui Parameter Farmakokinetik/ Farmakodinamik pada Plasma dan Jaringan Ayam Broiler. Jurnal Sain Vet 11(2): 119-125. 